Sains Malaysiana 49(12)(2020): 2891-2900

http://dx.doi.org/10.17576/jsm-2020-4912-02

\title{
Effect of Artificial Night Lighting on the Growth of Loose Head Lettuce in Hydroponic System
}

(Kesan Cahaya Malam Buatan terhadap Pertumbuhan Salad Loose Head dalam Sistem Hidroponik)

\author{
H.S. Chua*, Lai Siew Wei, Sivajothi Paramasivam, T.T. Goh \& Gee Chia Chen
}

\begin{abstract}
Supplemental LEDs lighting technology has been used as the promising lighting source in hydroponic cultures for sustainable production in urban agriculture. It could be the solution to address the growing concern about food safety, environmental impacts, bad weather, and efficient energy usage in agricultural production. In this study, the response of loose head lettuce toward the irradiance of the supplemental red-blue LED light with different power (Watt [W]) was investigated by comparing the treated lettuce with the lettuce cultured under only natural light. The lettuce plants were treated with red LED $(640-660 \mathrm{~nm})+$ blue LED $(440-450 \mathrm{~nm})$. The power output of the LEDs was specified to 3, 6, 9, 15 , and $20 \mathrm{~W}$. The lettuce plants were hydroponically cultured with $8 \mathrm{~h} \mathrm{red-blue} \mathrm{LEDs} \mathrm{light} \mathrm{exposure} \mathrm{(from} 12$ to 8 am) and $16 \mathrm{~h}$ without the red-blue LEDs light exposure (from $8 \mathrm{pm}$ to 12 am) at average air temperatures of $31 / 28{ }^{\circ} \mathrm{C}($ day/ night) for 50 days (7 weeks). On the harvesting day, the average shoot heights of the lettuce that was treated with 3, 6 , 9, 15, 20 LEDs and natural light were 25.00, 24.75, 20.75, 19.88, 17.63, and 12.63 cm, respectively. The lettuce that was exposed to the $3 \mathrm{~W}$ LEDs had the highest shoot height compared to those that were exposed to LEDs with other power outputs. The average fresh weights of the lettuce that was treated with 3, 6, 9, 15, $20 \mathrm{~W}$ LEDs and natural light were $27.25,24.75,21.25,19.88,18.38$, and $15.75 \mathrm{~g}$, respectively. The results showed that the fresh weight of the lettuce that was irradiated with $3 \mathrm{~W}$ LED light was significantly higher compared to the lettuce that was exposed to LEDs with other power outputs. Hence, it can be concluded that supplementary LEDs lighting technology can be used as an alternative lighting source to improve the growth of lettuce in hydroponic systems. Moreover, the use of $3 \mathrm{~W} L E D s$ in hydroponic systems could yield a higher shoot weight and fresh weight.
\end{abstract}

Keywords: Hydroponic systems; LED light; loose head lettuce; urban agriculture

\section{ABSTRAK}

Teknologi pencahayaan LED tambahan telah digunakan sebagai punca pencahayaan tambahan dalam pengkulturan hidroponik untuk pengeluaran lestari dalam pertanian bandar. Ia boleh menjadi penyelesaian kepada kebimbangan yang semakin meningkat berkenaan keselamatan makanan, kesan persekitaran, cuaca tidak baik dan penggunaan tenaga yang cekap dalam pengeluaran pertanian. Dalam kajian ini, tindak balas salad loose head terhadap pencahayaan LED merah-biru dengan kuasa yang berbeza (Watt [W]) telah dikaji dengan membandingkan salad terawat dengan salad terkultur di bawah cahaya semula jadi. Tumbuhan salad telah dirawat dengan LED merah (640-660 nm) + LED biru (440-450 nm). Output kuasa daripada LED telah dikelaskan kepada 3, 6, 9, 15, dan 20 W. Tumbuhan salad ini telah dikultur secara hidroponik dengan pendedahan kepada cahaya LED merah-biru selama 8 jam (dari 12 tengah malam ke 8 pagi) dan tanpa pendedahan kepada cahaya LED merah-biru selama 16 jam (dari 8 malam ke 12 tengah hari) pada purata suhu udara $31 / 28^{\circ} \mathrm{C}$ (siang/malam) selama 50 hari (7 minggu). Pada hari penuaian, purata ketinggian pucuk salad yang dirawat dengan 3, 6, 9, $20 \mathrm{~W}$ LED dan cahaya semula jadi masing-masing adalah 25.00. 24.75, 20.75, 19.88, 17.63 dan $12.63 \mathrm{~cm}$. Salad yang terdedah dengan 3 W LED mempunyai ketinggian pucuk yang tertinggi berbanding dengan salad yang terdedah kepada LED dengan output kuasa yang lain. Purata berat segar salad yang dirawat dengan 3, 6, 9, 15, 20 W LED dan cahaya semula jadi masing-masing adalah 27.25, 24.75, 21.25, 19.88, 18.38 dan 15.75 g. Keputusan kajian menunjukkan berat segar salad yang dipancarkan dengan cahaya $3 W$ LED adalah lebih ketara nilai beratnya berbanding dengan salad yang terdedah kepada LED dengan output kuasa yang lain. Oleh itu, kajian ini merumuskan bahawa teknologi pencahayaan LED tambahan dapat digunakan sebagai salah satu sumber cahaya alternatif untuk penambahbaikan penumbuhan salad dalam sistem hidroponik. Selain itu, penggunaan 3 W LED dalam sistem hidroponik dapat meningkatkan hasil berat pucuk dan berat segar.

Kata kunci: Cahaya LED; pertanian bandar; salad loose head; sistem hidroponik 


\section{INTRODUCTION}

The world population is predicted to grow from 7.6 to 8.6 billion by 2030 (Chua et al. 2019; United Nations 2017). As the population continue to grow, the demand for food will increase, the number of available lands will decrease due to rising needs for urbanization and carbon dioxide $\left(\mathrm{CO}_{2}\right)$ gas emission will also continue to increase at an alarming rate. Specifically, $\mathrm{CO}_{2}$ emission will increase by $1 \%$ when the world population increase by $1 \%$. An increased amount of $\mathrm{CO}_{2}$ in the atmosphere will deteriorate the indoor air quality as well as adversely impact the environment, for instance, causing global climate change (Shi 2003). According to Sevik et al. (2017), poor indoor air quality will affect one's health and performance since people spend most of their time indoors. Hence, plants are often times placed in indoor space for their photosynthesis capability which uses up carbon dioxide and releases oxygen.

Alternative farming techniques play an important role in sustaining the world growing population, for instance, soilless hydroponic systems. According to the publication from the United Nations (2019), approximately $68 \%$ of the world population will reside in urban areas by the year 2050. In urban areas with limited available land, hydroponic systems enable sufficient food production as plants in hydroponic systems grow by exposing only their roots to the nutrient solution. Hence, urban homes can now grow crops with hydroponic systems for self-supply. The LED light can be used as an artificial source of sunlight to stimulate plants growth in hydroponic systems. The advantages of LEDs include low power consumption, low radiating temperature, no emission of toxic and optimal light wavelengths for photosynthesis, which all these is lacking in traditional farming practices (Kobayashi et al. 2013; Singh et al. 2015). Besides, indoor farming crops are free from pollutants and pesticides. There are five major types of hydroponic systems: Nutrient film technique hydroponic system; deep water culture hydroponic system; Wick hydroponic system; Ebb and flow hydroponic system; drip hydroponic system.

There were studies on the lettuce growth under different colours and ratios of LEDs in a controlled environment. However, there is still lacking information on the power intensity of LEDs required to stimulate maximum plant growth. According to Lean (2017), approximately $0.94 \mathrm{~kg}$ of $\mathrm{CO}_{2}$ will be emitted to the atmosphere when $1 \mathrm{kWh}$ of electricity is produced from a coal-burning power plant. Therefore, it is crucial to determine the intensity of power required for maximum plant growth to effectively reduce cost and energy loss.

\section{MATERIALS AND METHODS}

A total of six (6) sets of the hydroponic system were set up in this study to investigate the effects of different power intensities of red-blue LED light on the growth of lettuce. Figure 1 illustrates the setup of the hydroponic systems with the same ratio of red-blue LEDs. The power intensity of the red-blue LEDs ranged from 3 to $20 \mathrm{~W}$. The data from the six (6) temperature sensors (ds18b20) and six (6) LDR photoresistor sensors (E088) were read using the Raspberry Pi 2 for data logging. The LDR photoresistors were interfaced with an ADC converter (MCP 3008). Another set of the hydroponic system was placed under normal greenhouse conditions without using red-blue LEDs as an artificial light source. The plants were harvested within seven weeks.

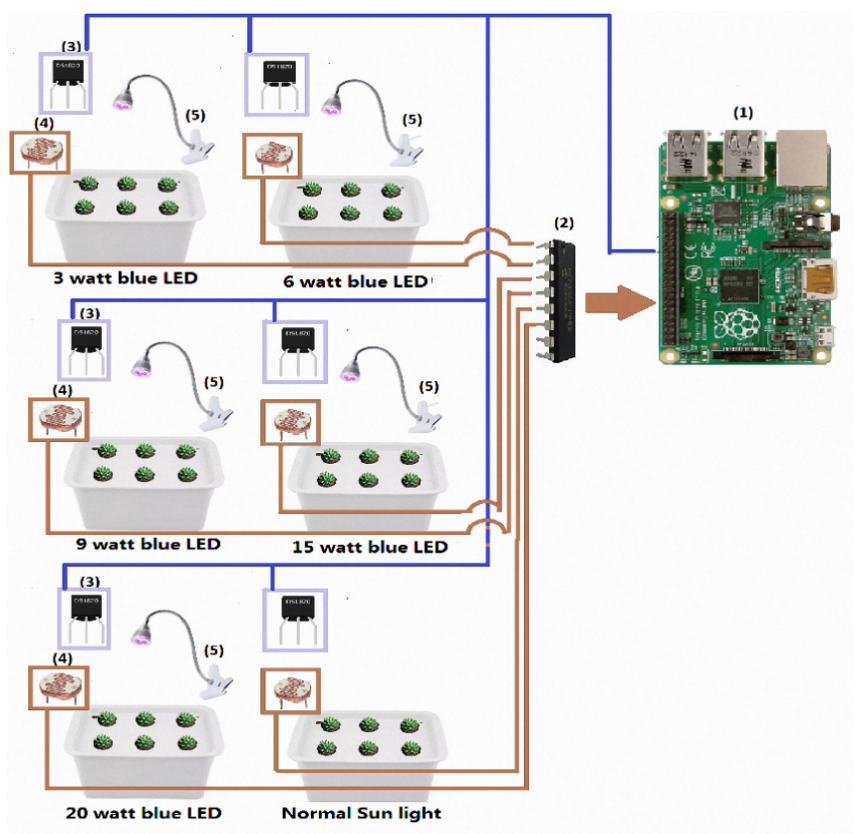

FIGURE 1. Six (6) sets of the hydroponic system: (1) Raspberry Pi 2, (2) ADC converter, (3) Temperature sensor, (4) LDR photoresistor, and (5) Red-Blue LED light 
The temperature was measured and maintained in the range between 20 and $30{ }^{\circ} \mathrm{C}$ for optimal growth. The LDR photoresistor sensors were used to maintain the light level within the optimum range of 300 to 3,000 lux. This study was performed following the 10/6/8 nature light/ dark/artificial light photoperiod.

\section{DEEP WATER CULTURE HYDROPONIC SYSTEM}

Deep water culture hydroponic system was used in this study due to its simple design and ability to reduce waste by recirculating the nutrients. This type of hydroponic system is suitable for small-size and short-term plants that can be harvested within two months such as lettuce.

\section{LETTUCE SEED TRANSPLANT PREPARATION}

The lettuce seeds, which were obtained from CityFarm Malaysia, were soaked for $36 \mathrm{~h}$. The seeds were then placed into the sponge cubes in the planting cups at a depth of $23 \mathrm{~mm}$ for germination. After that, the planting cups were put at the bottom of the tank. The appropriate nutrient solution, which was obtained from CityFarm Malaysia, was poured into the tank to a level of about 2 $\mathrm{cm}$. The seeds were allowed to grow for approximately two weeks. Then, the initial true leaves with equal size were selected and transplanted into the hydroponic systems with different LED lighting treatments. The lettuce was supplied with a nutrient solution which the $\mathrm{pH}$ and electrical conductivity (EC) were calibrated. The average temperature of the nutrient solution was maintained at $31 / 28^{\circ} \mathrm{C}$ (day/night), while the $\mathrm{pH}$ and $\mathrm{EC}$ of the nutrient solution were monitored and maintained at the range between 5.5 and 6.5 and 0.8 to $1.2 \mathrm{mS} / \mathrm{cm}$, respectively.
The average air temperature was maintained within the range of 27 and $30{ }^{\circ} \mathrm{C}$. The level of the nutrient solution was gradually reduced throughout this study for better plant growth.

\section{LIGHTING TREATMENTS}

In this study, five (5) sets of lettuce were grown hydroponically under the same ratio of the red-blue LED light. The power intensity and the number of LED light used in the hydroponic systems were (1) $3 \mathrm{~W}$ of 6 pieces LEDs (4 Red + 2 Blue), (2) $6 \mathrm{~W}$ of 60 pieces LEDs (40 Red +20 Blue), (3) $9 \mathrm{~W}$ of 60 pieces LEDs (44 Red + 22 Blue), (4) $15 \mathrm{~W}$ of 100 pieces LEDs (70 Red +30 Blue) and (5) $20 \mathrm{~W}$ of 114 pieces LEDs (84 Red + 34 Blue). Besides, there was another set of lettuce grown hydroponically under the normal greenhouse conditions without using the artificial LED light. The light intensity (lux) was measured using the LDR photoresistor sensors. The light distance was kept at $25 \mathrm{~cm}$ away from the lettuce using the adjustable clamp which came with the LED grow light. The lettuce was cultured following the $8 / 16$ (light/dark) photoperiod, where the lettuce was cultured with $8 \mathrm{~h}$ of red-blue LEDs light exposure and $16 \mathrm{~h}$ without the red-blue LEDs light exposure at average air temperatures of $31 / 28{ }^{\circ} \mathrm{C}$ (day/ night) for 50 days or 7 weeks (Table 1).

\section{PARAMETERS AND SPECIFICATION}

Two (2) sets of the three-level cabinet were used to place the hydroponic systems (Figure 2). Table 2 lists the methods used in this study to improve the accuracy of the results.

TABLE 1. Light duration of this study

\begin{tabular}{lcc}
\hline Daytime without LEDs support & Nighttime without LEDs support & Nighttime with LEDs support \\
\hline 8 am to $6 \mathrm{pm}$ & $6 \mathrm{pm}$ to $12 \mathrm{am}$ & 12 am to 8 am \\
\hline
\end{tabular}

TABLE 2. Hydroponic parameters (Folta \& Childers 2008; Lin et al. 2013)

\begin{tabular}{|c|c|c|}
\hline Parameters & Specification & Method to control \\
\hline Temperature & $20-30{ }^{\circ} \mathrm{C}$ & Digital temperature sensors were interfaced with Raspberry Pi \\
\hline Light level & $300-3,000$ lux & LDR photoresistor sensors were interfaced with Raspberry Pi \\
\hline Light distance & $25 \mathrm{~cm}$ below the LED & LED grow light comes with the adjustable clamp \\
\hline Light/Dark duration & $16 / 8$ & 24-h analogue timer switch to turn on and off the LED lighting \\
\hline Oxygenation & 8 h per day & 24-h analogue timer switch to turn on and off the water pump \\
\hline $\mathrm{pH}$ level & $5.5-6.5$ & $\mathrm{pH}$ meter to measure the $\mathrm{pH}$ level \\
\hline Electrical conductivity (EC) & $0.8-1.2 \mathrm{mS} / \mathrm{cm}$ & EC meter to measure the EC level \\
\hline Ratio of red-blue LEDs & for both LEDs & $\begin{array}{l}\text { Six pieces of } 3 \text { W LEDs } \\
\quad(4 \text { Red }+2 \text { Blue }) \\
60 \text { pieces of } 6 \text { W LEDs } \\
(40 \text { Red }+20 \text { Blue })\end{array}$ \\
\hline
\end{tabular}


MEASUREMENT OF PLANT GROWTH

A total of 24 lettuce samples (four samples from each treatment) were collected for the determination of the biometric measurements and comparison. The data were collected in two ways: (1) data logging using the
Raspberry Pi; (2) manual recording which included visual observation for leaf count, leaf area measurement, the number of days required for the formation of first leaf and height and fresh weight of the lettuce on the harvesting day.
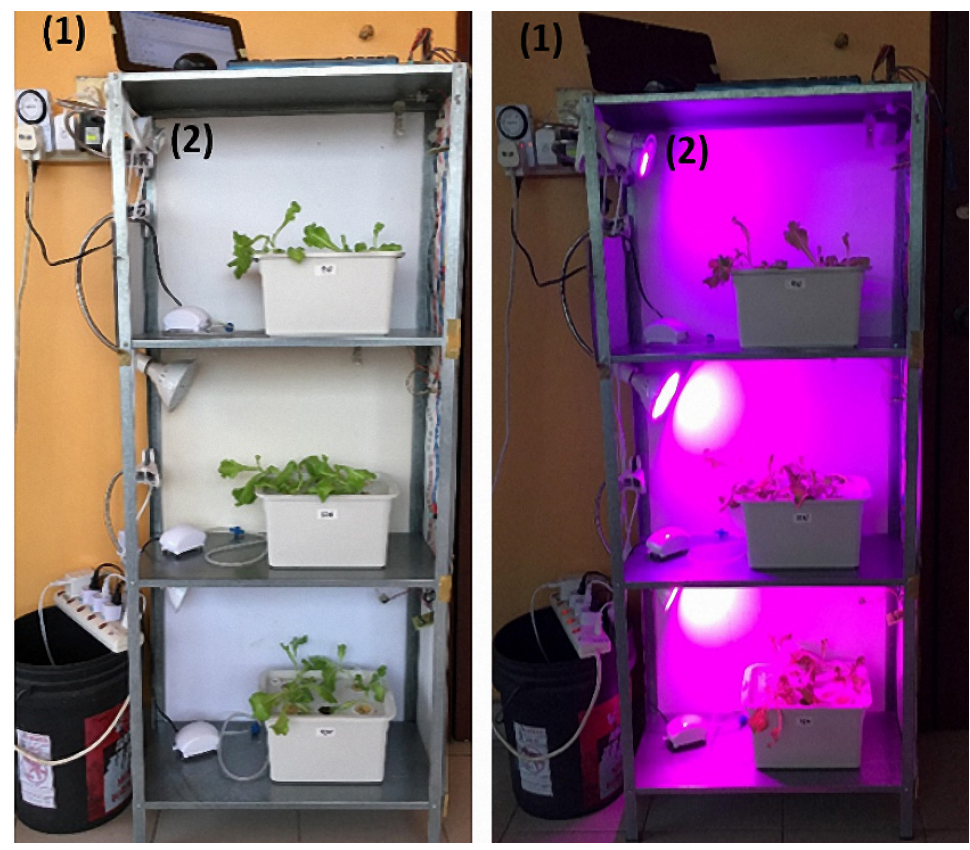

FIGURE 2. Set up of hydroponic system during day and night: (1)

Raspberry Pi 2, and (2) supplemental red-blue LED light

The data recorded by Raspberry Pi include the temperature and light intensity, which were then used to maintain the temperature and light intensity within the acceptable range.

\section{RESULTS AND DISCUSSION}

\section{SHOOT HEIGHT, LEAF COUNT, LEAF AREA AND ROOT} LENGTH OF THE LETTUCE

The loose head lettuce was hydroponically cultured for approximately seven weeks. The whole growth cycle of the lettuce could be divided into three stages as shown in Table 3. Throughout this study, four samples were collected from each treatment for growth analysis. The average shoot height and leaf count were measured at two-day intervals starting from Week 3 (16/12/2018) until Week 7 (21/01/2018). Figure 3 shows the average shoot heights of the lettuce treated with supplemental red-blue LED light and natural light. There was no significant difference in the average shoot height among the lighting treatments at the initial stage. However, the average shoot heights of the lettuce treated with supplementary red-blue LED light and the lettuce grew under natural sunlight started to vary significantly from day $4(20 / 12 / 2018)$ onwards.

TABLE 3. Progress of the lecture growth

\begin{tabular}{rcc}
\hline Date & Stage & Duration \\
\hline $02 / 12 / 2018$ & Stage 1 (seeds germination) & 2 weeks \\
$16 / 12 / 2018$ & Stage 2 (vegetative growth) & 5 weeks \\
$21 / 01 / 2019$ & Stage 3 (harvesting period) & 1 week \\
\hline
\end{tabular}


This indicates that the supplemental red-blue LED light helps in increasing the shoot height of the lettuce. The results of this study were congruent with the study conducted by Lin et al. (2013). The lettuce treated with 9 W LEDs were the fastest-growing set at the first 25 days. From day 25 to day 28 , the lettuce treated with $15 \mathrm{~W}$ LEDs were the fastest-growing set. While from day 28 to day 49, the lettuce treated with $6 \mathrm{~W}$ LEDs had the highest shoot height. Lastly at day 50 , the lettuce treated with $3 \mathrm{~W}$ LEDs had the highest shoot height. On the harvesting day (21/01/2019), the average shoot heights of the lettuce that was irradiated with $3 \mathrm{~W}$ LEDs, $6 \mathrm{~W}$ LEDs and natural light were $25.00,24.75$ and $12.63 \mathrm{~cm}$, respectively. The shoot heights of the lettuce that were exposed to 3 and $6 \mathrm{~W}$ LEDs were significantly higher than that of the lettuce cultured under natural sunlight. Whereas, there was no significant difference in the shoot heights of the lettuce treated with 3 and 6 W LEDs. Figure 4 shows the average leaf count of the lettuce under different lighting treatments. The results showed that the leaf counts of the lettuce were similar among the lighting treatments at the initial stage. However, the leaf counts of the lettuce treated with supplementary red-blue LED light and the lettuce grew under natural sunlight started to vary significantly from day 4 onwards.

This indicates that LED light increases the leaf density of lettuce. On the harvesting day (21/01/2019), the average leaf count of the lettuce that were irradiated with $3,6,9,15$, and $20 \mathrm{~W}$ LEDs and sunlight were 10, 11, 9, 8, and 7 pcs, respectively. The lettuce that was cultured under $6 \mathrm{~W}$ LEDs treatment had the highest number of leaves. Referring to Figure 5, the $\mathrm{pH}$ level varied significantly between the lettuce treated with supplementary red-blue LEDs and the lettuce grew under natural sunlight. This indicates that LED light stimulates the enlargement of the lettuce leaf. In the previous study conducted by Folta and Childers (2008), it was observed that the red light receptor and blue light receptor were the main photoreceptors that controlled the plant photomorphogenic process in response to photon interception, where the blue light receptor stimulated the leaf enlargement and

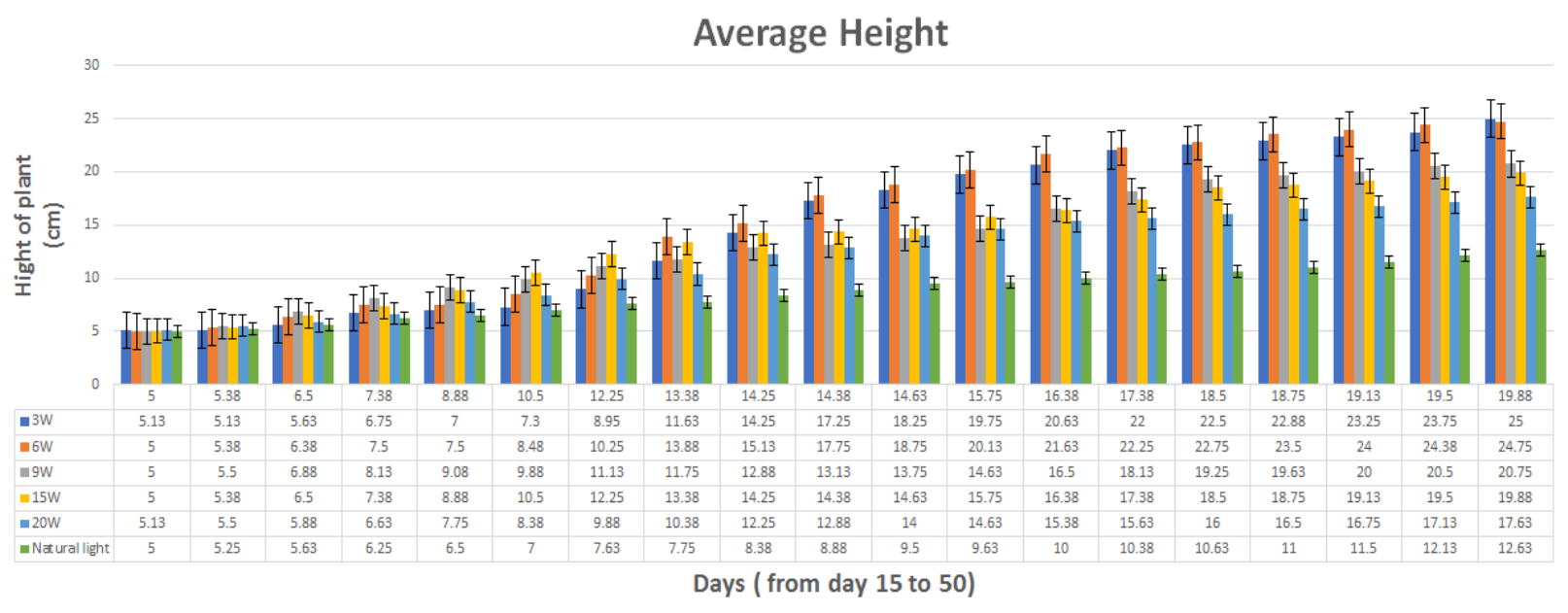

FIGURE 3. Average shoot height under different treatments

regulated the genetic manifestation. On the harvesting day $(21 / 1 / 2019)$, the average leaf area of the lettuce that was irradiated with $3,6,9,15$, and $20 \mathrm{~W}$ LEDs and sunlight were $108.38,109.56,90.88,89.73,89.70$, and $88.95 \mathrm{~cm}^{2}$, respectively (Figure 6). The leaf area of the lettuce that was exposed to 3 and $6 \mathrm{~W}$ LEDs were larger compared to the lettuce cultured under LEDs with other power intensities and natural sunlight. Figure 7 shows the average root length of the lettuce under different lighting treatments. On the harvesting day $(21 / 1 / 2019)$, the average root length of the lettuce that was irradiated with $3,6,9,15$, and $20 \mathrm{~W}$ LEDs and sunlight were $10.00,13.00,9.50,8.38,5.63$, and 6.25 $\mathrm{cm}$, respectively. The lettuce that was cultured under $6 \mathrm{~W}$ LEDs treatment had the longest root length. This indicates that $6 \mathrm{~W}$ LED light helps elongate the lettuce root. The results of this study were congruent with the study by Sabzalian et al. (2014), which also showed that red-blue LED incubator produced plants with higher shoots, longer roots, and higher fresh weights. 
Average leaf (pcs)

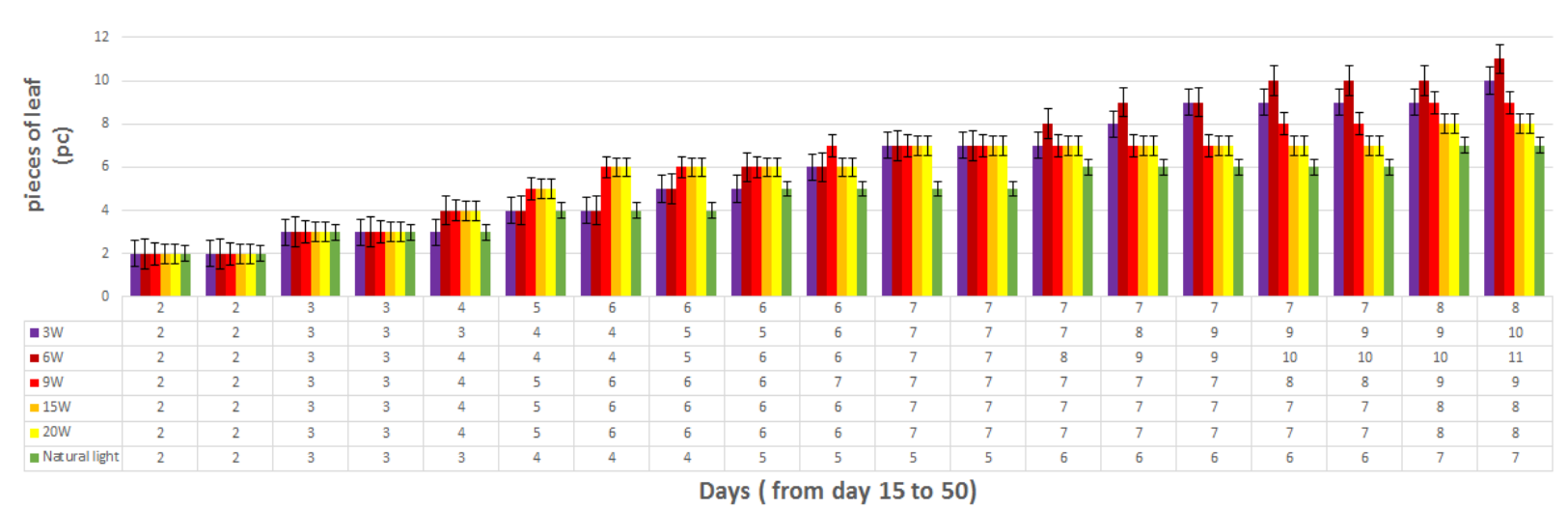

FIGURE 4. Average leaf count (pcs) under different treatments

PH Level

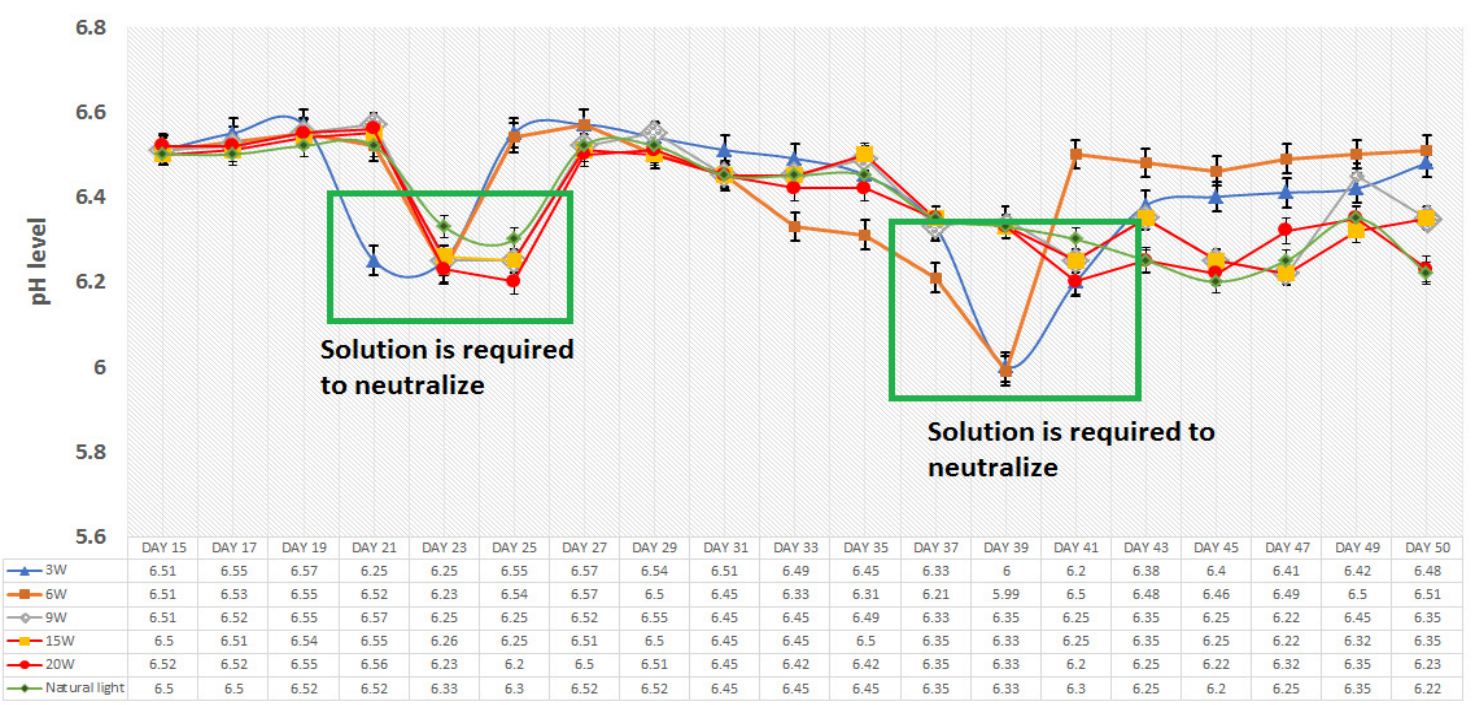

FIGURE 5. Average $\mathrm{pH}$ under different treatments

FRESH WEIGHT OF THE LETTUCE

The average fresh weights of the lettuce that was cultured under different lighting treatments are shown in Figure 8 . On the harvesting day (21/01/2019), the average fresh weights of the lettuce that was irradiated with $3,6,9,15$, and $20 \mathrm{~W}$ LEDs and natural light were 27.25, 24.75, 21.25,
$19.88,18.38$, and $18.75 \mathrm{~g}$, respectively. The results show that the fresh weights of the lettuce that was irradiated with $3 \mathrm{~W}$ LEDs and $6 \mathrm{~W}$ LEDs were significantly higher compared to that of the lettuce that was cultured under other lighting treatments. The $6 \mathrm{~W}$ was significantly higher than $3 \mathrm{~W}$. 


\section{DISCUSSION}

This study has demonstrated that the combination of supplemental red and blue LED light could be used as the light source in hydroponic systems to effectively stimulate the growth of lettuce. Red and blue lights are the major energy sources for photosynthetic $\mathrm{CO}_{2}$ assimilation in plants. Blue light with the wavelength of 450 to $495 \mathrm{~nm}$ promotes the formation of chlorophyll which helps the plant in increasing the energy intake from the light source. While red light with the wavelength of 610 to $720 \mathrm{~nm}$ promotes the peak absorption of chlorophyll which speeds up seed germination (Sabzalian et al. 2014). In this study, the lettuce that was cultivated under the irradiation of different power intensities of supplemental red-blue LED light yielded a higher shoot and root length, higher number of leaves, larger leaf area, higher fresh weight, and healthier appearance compared to the lettuce that was cultivated under natural light or without supplemental red-blue LEDs. When comparing the effects of 3 and $6 \mathrm{~W}$ LEDs on the lettuce growth in terms of the average shoot height and leaf count, the results showed that the values of these two parameters were higher when the lettuce was treated with $6 \mathrm{~W}$ LEDs. The presumption is that the lettuce growth will drop if 1 or $2 \mathrm{~W}$ LEDs are used. Table 3 shows the comparison of EC levels of the nutrient solutions with and without using the supplemental red-blue LEDs as the artificial light source to promote the lettuce growth. The result showed that the EC level of each lighting treatment was within the acceptable range between 0.5 and 1.5 $\mathrm{mS} / \mathrm{cm}$. The EC level of a hydroponic system acts as the controlling variable which is important to stimulate a better growth of lettuce. The result showed that the higher the wattage, the more heat was produced, and the higher the concentration of nutrients. This indicates that plants use up more water instead of nutrient which cause the increase of EC level at higher power wattage of supplemental red-blue LED (Gray 2019). Table 4 shows the comparison between soil farming and hydroponic farming. Domingues et al. (2012) compared the growth of lettuce under two conditions: Automated hydroponic system and conventional soil farming. The result of that study showed that automated hydroponic system had a shorter harvest duration (64 against 71 days) with reduced labour, better control of conductivity and $\mathrm{pH}$ and better productivity. Kamaluddin and Zwiazek (2012) stated that low $\mathrm{pH}$ will cause a rapid decrease in hydraulic conductivity and water floor flow rate in seedling roofs. Also, Zhang et al. (2014) reported that low $\mathrm{pH}$ will inhibit $\mathrm{CO}_{2}$ assimilation and subsequently lower the photosynthesis rate, resulting in lower average shoot height and leaf count. This study showed that the lettuce that was cultured under hydroponic method had a short harvest duration and the duration was further shortened with the application of artificial light source.

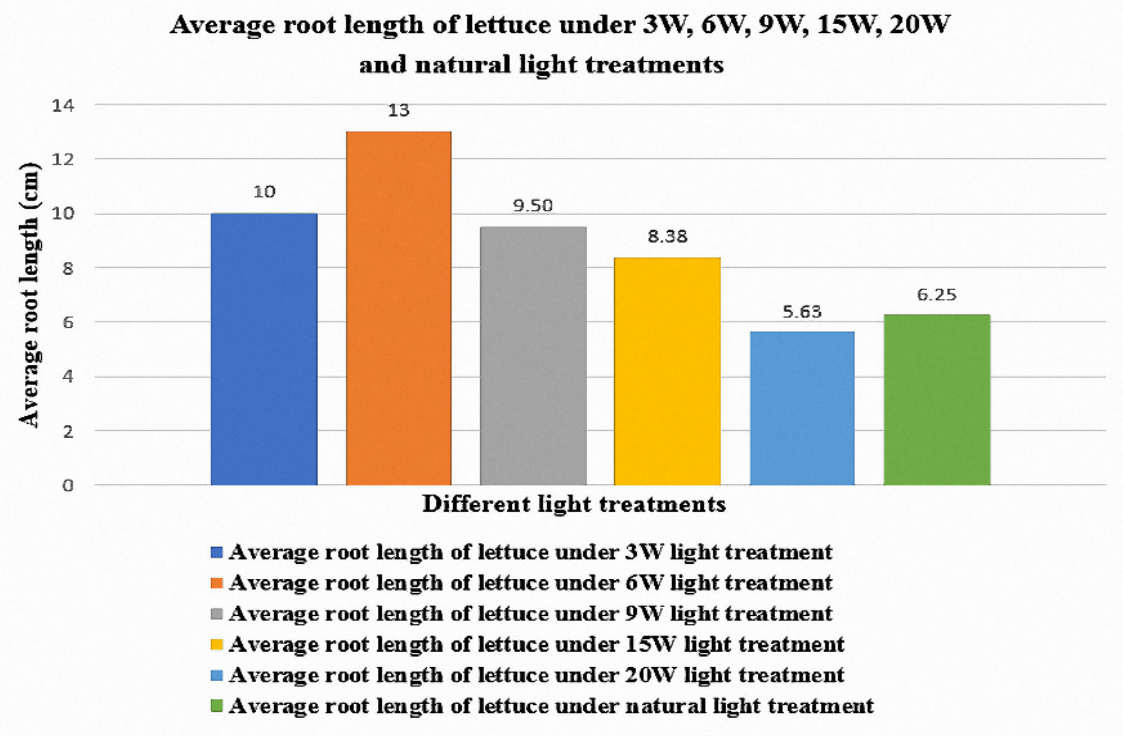

FIGURE 6. Average leaf area under different treatments 


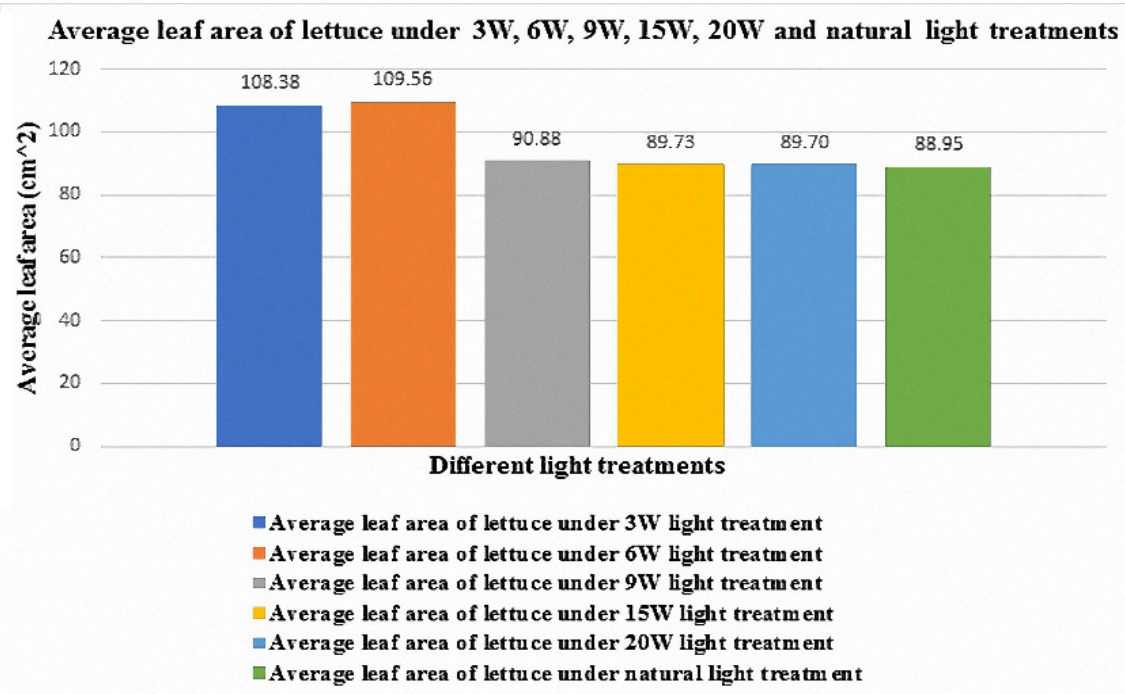

FIGURE 7. Average root length under different treatments

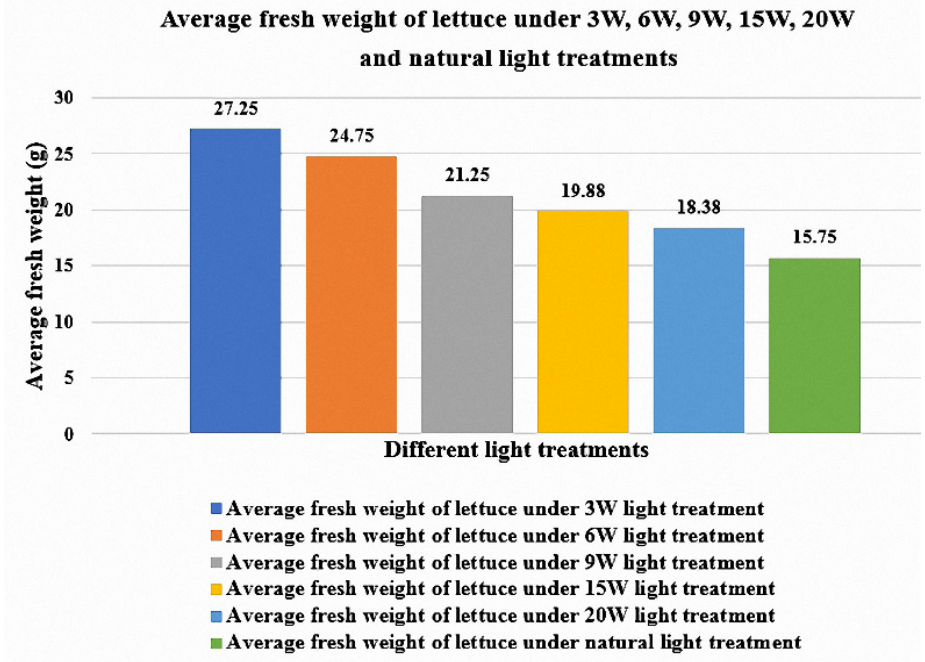

FIGURE 8. Average fresh weight under different treatments

TABLE 3. Comparison of EC level with and without supplemental red-blue LEDs

\begin{tabular}{lcccccc}
\hline & \multicolumn{3}{c}{ With red-blue LEDs } & Without red-blue LEDs \\
\hline Type of treatment & $3 \mathrm{~W}$ & $6 \mathrm{~W}$ & $9 \mathrm{~W}$ & $15 \mathrm{~W}$ & $20 \mathrm{~W}$ & Natural light \\
Average EC level & 1.004 & 1.006 & 1.027 & 1.039 & 1.058 & 1.018 \\
$(\mathrm{mS} / \mathrm{cm})$ & & & & & & \\
\hline
\end{tabular}


TABLE 4. Comparison between soil and hydroponic farming

\begin{tabular}{lll}
\hline \multicolumn{1}{c}{ Soil farming } & Hydroponic farming & $\begin{array}{l}\text { Hydroponic farming with } \\
\text { artificial light }\end{array}$ \\
\hline - Higher water usage & - Lower water usage & - Lower water usage \\
- Required spacious & - Required smaller land & - Required smaller land \\
land & space & space \\
- Pollution from & - Less pollution from & - Less pollution from \\
herbicides and & herbicides and pesticides & herbicides and pesticides \\
pesticides & - No bad weather concerns & - No bad weather concerns \\
- Bad weather concern & - Shorter harvest cycle & - Shorter harvest cycle \\
- Long harvest cycle & - Higher initial cost & - Higher yields \\
- Lower initial cost & & - Higher initial cost \\
\hline
\end{tabular}

From 2006 to 2016, the price of solar PV had dropped by about $58 \%$. Besides, the PV system has been matured with MPPT algorithm (Mohamed et al. 2018; Yung et al. 2019). Thus, solar PV can be used in hydroponic farming to create a mutually beneficial ecosystem.

\section{EFFECT OF TEMPERATURE ON INITIAL GERMINATION}

Temperature is one of the main factors that affect initial germination. According to Motsa et al. (2015), optimum germination occurred when temperatures range between 29 and $32{ }^{\circ} \mathrm{C}$. Figure 9 shows the average day and night temperatures under different lighting treatments. The results showed that the temperature varied among the lighting treatments. The hydroponic systems treated with $3 \mathrm{~W}$ LEDs, $6 \mathrm{~W}$ LEDs and natural light had lower night temperatures, which could be the main cause for the lower average shoot height and leaf count in these three hydroponic systems compared to the other three hydroponic systems (Figures $3 \& 4$ ).

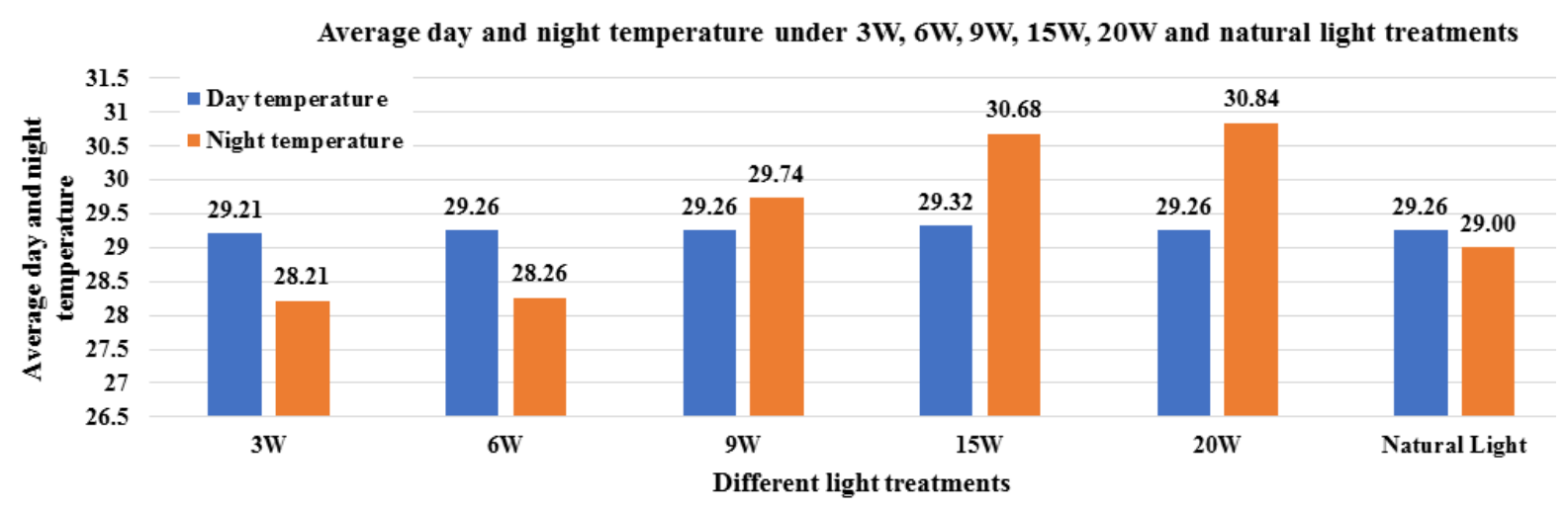

FIGURE 9. Graph of the average day and night temperature versus different light treatments

\section{CONCLUSION}

In conclusion, the power intensity of LED lighting technology impacts the plant growth and morphological parameters. The lettuce that was cultivated under the irradiation of $6 \mathrm{~W}$ supplemental red-blue LED light had a higher number of leaves, larger leaf area, elongated root and shoot height, higher fresh weight and healthier appearance. In other words, supplementary LED lighting technology could be used as the alternative lighting source to improve the lettuce growth in hydroponic systems. 
However, since this study was conducted at the normal outdoor temperature in Malaysia, the optimal power intensity required for maximum plant growth may vary if similar research is carried out at a lower temperature. In order to further optimize the yield, a larger range of power intensity could be studied in the future for determination of the optimal power intensity.

\section{ACKNOWLEDGEMENTS}

The authors would like to acknowledge the financial support from UOW Malaysia KDU University College, Utropolis Glenmarie, Postgraduate Research Centre (PGRC), Malaysia.

\section{REFERENCES}

Chua, H.S., Bashir, M.J.K., Tan, K.T. \& Chua, H.S. 2019. A sustainable pyrolysis technology for the treatment of municipal solid waste in Malaysia. In AIP Conference Proceedings, AIP Publishing LLC 2124(1): 020016.

Domingues, D.S., Takahashi, H.W., Camara, C.A. \& Nixdorf, S.L. 2012. Automated system developed to control pH and concentration of nutrient solution evaluated in hydroponic lettuce production. Computers and Electronics and Agriculture 84: 53-61.

Folta, K.M. \& Childers, K.S. 2008. Light as a growth regulator: Controlling plant biology with narrow-bandwidth solidstate lighting systems. HortScience 43(7): 1957-1964.

Gray, L. 2019. Lighting and economic considerations for a hydroponic s-based greenhouse at tri cycle farms. Biological and Agricultural Engineering Undergraduate Honors Theses. University of Arkansas. p. 58.

Kamaluddin, M. \& Zwiazek, J.J. 2004. Effects of root medium $\mathrm{pH}$ on water transport in paper birch (Betula papyrifera) seedlings in relation to root temperature and abscisic acid treatments. Tree Physiology 24(10): 1173-1180.

Kobayashi, K., Amore, T. \& Lazaro, M. 2013. Light-emitting diodes (LEDs) for miniature hydroponic lettuce. Optics and Photonics Journal 2013: 74-77.

Lean, R.M. 2017. How Much $\mathrm{CO}_{2}$ Emissions Per Kwh of Electricity? https://carbonpositivelife.com/ $\mathrm{co}_{2}$-per-kwhof-electricity/. Accessed on 9 October 2018.

Lin, K.H., Huang, M.Y., Huang, W.D., Hsu, M.H., Yang, Z.W. \& Yang, C.M. 2013. The effects of red, blue, and white lightemitting diodes on the growth, development, and edible quality of hydroponically grown lettuce (Lactuca sativa L. var. capitate). Scientia Horticulturae 150: 86-91.

Motsa, M.M., Slabbert, M.M., van Averbeke, W. \& Morey, L. 2015. Effect of light and temperature on seed germination of selected African leafy vegetables. South African Journal of Botany 99: 29-35.
Sabzalian, M.R., Heydarizadeh, P., Zahedi, M., Boroomand, A., Agharokh, M., Sahba, M.R. \& Schoefs, B. 2014. High performance of vegetables, flowers, and medicinal plants in a red-blue LED incubator for indoor plant production. Agronomy for Sustainable Development 34(4): 879-886.

Sevik, H., Cetin, M., Guney, K. \& Belkayali, N. 2017. The influence of house plants on indoor $\mathrm{CO}_{2}$. Polish Journal of Environment Studies 26(4): 1643-1651.

Shi, A. 2003. The impact of population pressure on global carbon dioxide emissions, 1975-1996: Evidence from pooled cross-country data. Ecological Economics 44(1): 29-42.

Singh, D., Basu, C., Meinhardt-Wollweber, M. \& Roth, B. 2015. LEDs for energy efficient greenhouse lighting. Renewable Sustainable Energy Reviews 49: 139-147.

United Nations. 2019. World Urbanization Prospects: The 2018 Revision (ST/ESA/SER.A/420) Report. Department of Economic and Social Affairs, Population Division.

United Nations. 2017. World Population Prospects: The 2017 Revision. https://www.un.org/development/desa/ publications/world-population-prospects-the-2017-revision. html.

Yung, Y.K., Chua, H.S., Bashir, M.J.K. \& Albert, F.Y.C. 2019. Central Composite Design (CCD) for parameters optimization of Maximum Power Point Tracking (MPPT) by Response Surface Methodology (RSM). Journal of Mechanics of Continua and Mathematical Sciences 1: 259.

Zain, A.O.M., Shen, C.H., Govinda, S., Albert, F.Y. \& Al-Talib, A.A. 2018. Matlab design and power analysis of MPPT controller for solar PV using perturb and observation algorithm. Advanced Science Letters 24(11): 9001-9005.

Zhang, C., Meng, P., Li, J. \& Wan, X. 2014. Interactive effects of soil acidification and phosphorus deficiency on photosynthetic characteristics and growth in Juglans regia seedlings. Chinese Journal of Plant Ecology 38(12): 1345-1355.

Lai Siew Wei, Sivajothi Paramasivam, T.T. Goh \& Gee Chia Chen School of Electrical and Electronics Engineering

University of Wollongong Malaysia KDU

Glenmarie Campus

40150 Shah Alam, Selangor Darul Ehsan

Malaysia

H.S. Chua*

School of Mechatronic Engineering

University of Wollongong Malaysia KDU

Glenmarie Campus

40150 Shah Alam, Selangor Darul Ehsan

Malaysia

*Corresponding author; email: hs.chua@kdu.edu.my

Received: 3 May 2020

Accepted: 28 July 2020 